\title{
Batch and Continuously Operated Electrooxidation Process for Removal of Phenol from Aqueous Solutions
}

\author{
DIMITRIOS STERGIOPOULOS ${ }^{1,3}$, KONSTANTINOS DERMENTZIS $^{1,2^{*}}$, \\ KOKKONI KARAKOSTA ${ }^{1,2}$, PANAGIOTIS GIANNAKOUDAKIS ${ }^{3}$ \\ ${ }^{1}$ International Hellenic University, Department of Chemistry, 65404 Agios Loukas, Kavala, Greece \\ ${ }^{2}$ Hephaestus Advanced Research Laboratory, 65404 Agios Loukas, Kavala, Greece \\ ${ }^{3}$ Aristotle University of Thessaloniki, Department of Chemistry, Thessaloniki, Greece
}

Abstract: The treatment of aqueous phenol solutions is studied using the electrooxidation process with boron doped diamond (BDD) electrodes. The reduction of phenol concentration is followed by measurements of $U V$-Vis spectrophotometry and COD. Parameters affecting the efficiency of the electrooxidation process, such as solution $\mathrm{pH}$, applied current density, initial phenol concentration, flow rate and conductivity are investigated. Effective and complete removal of phenol (>99\%) is achieved from solutions with initial phenol concentration of $100 \mathrm{mg} / \mathrm{L}$ in both, batch and continuously operated process.

Keywords: BDD electrodes, electrochemical oxidation, intermediate oxidizing agents, phenol

\section{Introduction}

Phenol and its derivatives constitute a serious environmental problem as they are particularly toxic pollutants for aquatic flora and fauna. These compounds are released to the environment from various industrial activities: petroleum, petrochemicals, pharmaceuticals, paper mill, plastics and food processing units. Phenolic compounds are recalcitrant to conventional treatment methods and are classified in the priority list of hazardous chemical compounds. Several treatment methods for removal of phenol have been proposed, such as biological treatment [1], adsorption [2,3], oxidation [4] and photochemical degradation [5].

Electrochemistry offers new solutions for efficient destruction of toxic and recalcitrant organic compounds, such as phenol [6-10]. The advanced electrochemical oxidation processes (AEOPs), such as electro-Fenton [11-13] and electrooxidation with dimensionally stable anodes (DSA) are based on the formation of the powerful oxidizing agent, the hydroxyl radical $\mathrm{OH}^{*}$ and are, therefore, emergent and promising processes for pollution abatement.

The boron-doped diamond (BDD) electrode is one of the most state of the art currently available DSA-type electrodes with the highest anodic potential of 2.85 Volts concerning oxygen development in aqueous solutions. When diamond electrodes are used for electrolysis of water, the most powerful intermediate oxidizing agents develop, such as free hydroxyl radicals $\left(\mathrm{OH}^{*}\right)$, ozone $\left(\mathrm{O}_{3}\right)$, hydrogen peroxide $\left(\mathrm{H}_{2} \mathrm{O}_{2}\right)$ etc. In addition, atomic chlorine $\left(\mathrm{Cl}^{\circ}\right)$ or peroxodisulfate ions $\left(\mathrm{S}_{2} \mathrm{O}_{8}{ }^{2-}\right)$ can be formed, dependent on the electrolyte contained in the treated water or wastewater e.g. $\mathrm{NaCl}$ or $\mathrm{Na}_{2} \mathrm{SO}_{4}$. BDD electrodes are also chemically and mechanically stable and, compared to other electrodes are the most suited for performing AEOPs with very high current efficiencies $[14,15]$. AEOPs are characterized by the production and use of these powerful oxidizers for the oxidative destruction of organic substances.

Several researchers reported the anodic oxidative destruction of phenol either in a batch wise [1618] or in a continuously operated electrooxidation process [19-21]. As far as we are aware no other paper appeared in literature up to know combining the two operation modes.

In this work we studied the oxidative degradation of phenol from aqueous solutions by anodic oxidation at BDD anodes in both, batch wise and continuously operated processes. All parameters affecting the efficiency of the electrooxidation process, such as solution $p \mathrm{H}$, applied current density, 
initial phenol concentration, temperature, flow rate, conductivity and time of electroprocessing were tested and optimal conditions investigated.

\section{Materials and methods Chemicals}

Phenol, $\mathrm{Na}_{2} \mathrm{SO}_{4}, \mathrm{H}_{2} \mathrm{SO}_{4}$ and $\mathrm{NaOH}$ were of analytical grade (Merck). $p \mathrm{H}$ was adjusted with $0.1 \mathrm{M}$ solutions of $\mathrm{H}_{2} \mathrm{SO}_{4}$ and $\mathrm{NaOH}$ as required. A stock aqueous phenol solution of concentration 1000 $\mathrm{mg} / \mathrm{L}$ was prepared by dissolution of the appropriate amount of phenol in deionized water and sample solutions by dilution.

\section{Apparatus}

A laboratory model DC power supply apparatus (Agilent E3612A, USA) was used to maintain constant DC current and measurements of voltage and current. Conductivity was measured by means of a conductometer (inoLab Cond. Level 1, WTW). The solution $p \mathrm{H}$ was measured by a WTW $\mathrm{pH}$ meter.

\section{Electrochemical cell}

The batch electrolysis was conducted at room and elevated temperature in a cylindrical glass cell of $500 \mathrm{~mL}$ in which $250 \mathrm{~mL}$ of wastewater were placed and slowly stirred with a magnetic bar at 500 rpm. A graphite plate cathode (Graphite, Germany) and a BDD plate anode (DiaCCom, Germany) of size $10 \mathrm{~cm} \times 5 \mathrm{~cm} \times 0.2 \mathrm{~cm}$ immersed to a $6 \mathrm{~cm}$ depth with an effective area of $30 \mathrm{~cm}^{2}$ each were used as electrodes in the experiments. The inter-electrode distance was $1 \mathrm{~cm}$. The continuous electrooxidation experiments were carried out in a self made flow-through cell with same electrodes (a graphite cathode and a BDD anode), a flow meter and a peristaltic pump.

Samples were extracted every $10 \mathrm{~min}$ and filtered using Whatman filter paper (Grade 40) and brought to analysis.

\section{Analytical procedure}

UV-VIS Spectrophotometry (HITACHI U-2000, Japan) was used for spectroscopic determination of phenol concentrations by analyzing the color resulting from the reaction of phenol with 4aminoantipyrine at $500 \mathrm{~nm}$. Samples were filtered using polytetrafluorethylene filters with a pore size of $0.45 \mu \mathrm{m}$ (Whatman). All analyses were carried out in duplicate for reproducibility. The chemical oxygen demand (COD) was analyzed using a COD reactor (Thermoreaktor TR 420, MERCK) and a direct reading spectrophotometer (Spectroquant Pharo100, MERCK).

Conductivity was measured by means of a conductometer (WTW). The $\mathrm{pH}$ and the temperature were measured using a Hanna $\mathrm{pH}$-meter. Both, batch and continuous electrochemical processes have been conducted. The wastewater was circulated by a peristaltic pump.

The percentage removal efficiency of phenol (\% R) was calculated from equation (1):

$$
\% \mathrm{R}=\frac{\mathrm{C}_{0-} \mathrm{C}_{\mathrm{t}}}{\mathrm{C}_{0}} \times 100
$$

where $C_{o}$ is the initial and $C_{t}$ the concentration of phenol at time $t$.

\section{Results and discussions}

\section{Electrochemical advanced oxidation processes (EAOPs)}

The boron doped diamond (BDD) electrodes are the most state of the art, currently available electrodes with the highest anodic overvoltage of 2.85 volts concerning oxygen evolution in aqueous solutions $[16,17]$. When diamond electrodes are used for electrolysis of water, the most powerful oxidizing agents develop, such as free hydroxyl radicals $\left(\mathrm{OH}^{*}\right)$, ozone $\left(\mathrm{O}_{3}\right)$, Hydrogen peroxide $\left(\mathrm{H}_{2} \mathrm{O}_{2}\right)$ 
etc. In addition, atomic chlorine $\left(\mathrm{Cl}^{*}\right)$ or peroxodisulfate ions $\left(\mathrm{S}_{2} \mathrm{O}_{8}{ }^{2-}\right)$ can be formed, dependent on the electrolyte contained in the treated water or wastewater e.g. $\mathrm{NaCl}$ or $\mathrm{Na}_{2} \mathrm{SO}_{4}$ respectively. BDD electrodes are also chemically and mechanically stable and, compared to other electrodes are most suited for performing EAOPs with very high current efficiencies. EAOPs are characterized by the production and use of hydroxyl radicals for the oxidative destruction of organic compounds.

According to reaction equation (2) for the complete oxidation of one molecule phenol $28 \mathrm{OH}^{*}$ radicals are involved, which of course originate from equivalent water molecules oxidized at the BDD anode:

$$
\mathrm{C}_{6} \mathrm{H}_{5} \mathrm{OH}+28 \mathrm{OH}^{*} \rightarrow 6 \mathrm{CO}_{2}+17 \mathrm{H}_{2} \mathrm{O}
$$

\section{Batch wise electrooxidation process}

The batch wise operated electrooxidation process is affected by several factors, such as $\mathrm{pH}$, applied current density, initial phenol concentration and time of electroprocessing.

\section{Effect of $p \mathbf{H}$}

The $p \mathrm{H}$ value of the treated solution has a marked effect on the efficiency of phenol and phenolic compounds degradation by the electrooxidation process [21]. In order to show the dependence from initial solution $p \mathrm{H}$, the electrooxidation process was tested at three different initial $\mathrm{pH}$ values of 5,7 and 9 using $250 \mathrm{~mL}$, solution volume with initial phenol concentration $100 \mathrm{mg} / \mathrm{L}$, room temperature 25 ${ }^{0} \mathrm{C}$ and constant current density $20 \mathrm{~mA} / \mathrm{cm}^{2}$.

As illustrated in Figure 1, the degradation of phenol occurs slightly faster at $p \mathrm{H} 7$ followed at $\mathrm{pH} 5$ and $p \mathrm{H}$ 9. This $p \mathrm{H}$ dependence of the electrooxidation process efficiency should be attributed to the number or the stability of the produced hydroxyl radicals. Our results are in good agreement with the findings of Weiss, 1956 [22] and Buxton et al., 1988 [23], who reported a marked reduction in the stability of free hydroxyl radicals, $\mathrm{OH}^{*}$ in both, acidic and alkaline solutions, due to following reactions (3-5), in acidic region:

$$
\begin{array}{ll}
\mathrm{H}^{+}+\mathrm{OH}^{*} \rightarrow \mathrm{H}_{2} \mathrm{O}^{*} & \text { (protonation) } \\
\mathrm{H}_{2} \mathrm{O}^{*}+\mathrm{H}_{2} \mathrm{O} \rightarrow \mathrm{H}_{2} \mathrm{O}^{*} \cdot \mathrm{H}_{2} \mathrm{O} & \text { (hydration) }
\end{array}
$$

and in alkaline region:

$$
\mathrm{OH}^{*}+\mathrm{OH}^{-} \rightarrow * \mathrm{O}^{-}+\mathrm{H}_{2} \mathrm{O}
$$

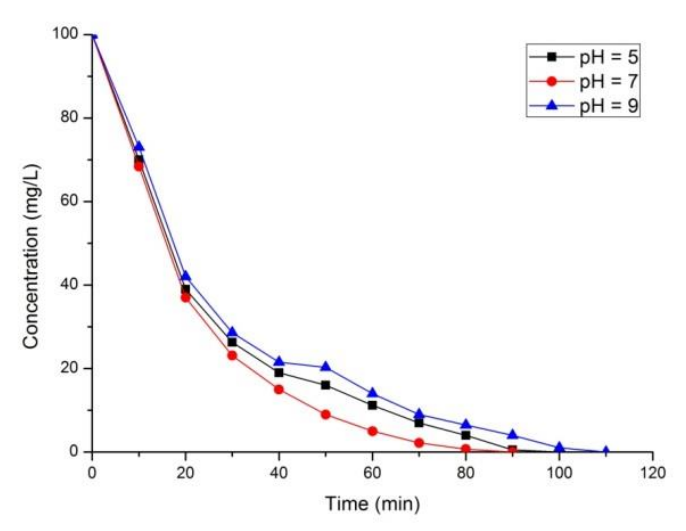

Figure 1. Residual phenol concentration versus time at various $p \mathrm{H}$ values

\section{Effect of applied current density}

For selection of the optimal applied current density, measurements were performed with constant initial phenol concentrations of $100 \mathrm{mg} / \mathrm{L}, p \mathrm{H}$ 7, room temperature $25{ }^{\circ} \mathrm{C}$ and various current densities 
20-80 mA/ $\mathrm{cm}^{2}$. According to investigations of Kraft et al. 2003 [14], Troster et al. 2002 [15] and Martnez-Huitle et al. 2014 [24], an increased current density generates more hydroxyl radicals and other strong oxidizing agents and accelerates the electrooxidation process. It can be seen in Figure 2 that for the applied current densities of 20,40 and $80 \mathrm{~mA} / \mathrm{cm}^{2}$, the corresponding electroprocessing times for complete destruction of phenol are 90, 30 and $10 \mathrm{~min}$. It implies that an increase in current density brings about not only a proportional but a relatively higher increase in generation of free hydroxyl radicals and therefore, a more accelerated oxidative destruction of phenol. This is indicated by the much shorter needed electrolysis times than the proportional. The corresponding electrical energy consumptions for the above three applied current densities are $29.92,23.87$ and $18.47 \mathrm{kWh} / \mathrm{m}^{3}$ respectively. Namely, less electrical energy is consumed at higher than at lower current densities due to the substantially higher increase of the electrochemically generated hydroxyl radicals and therefore, the far shorter time needed for completing the electrolysis.

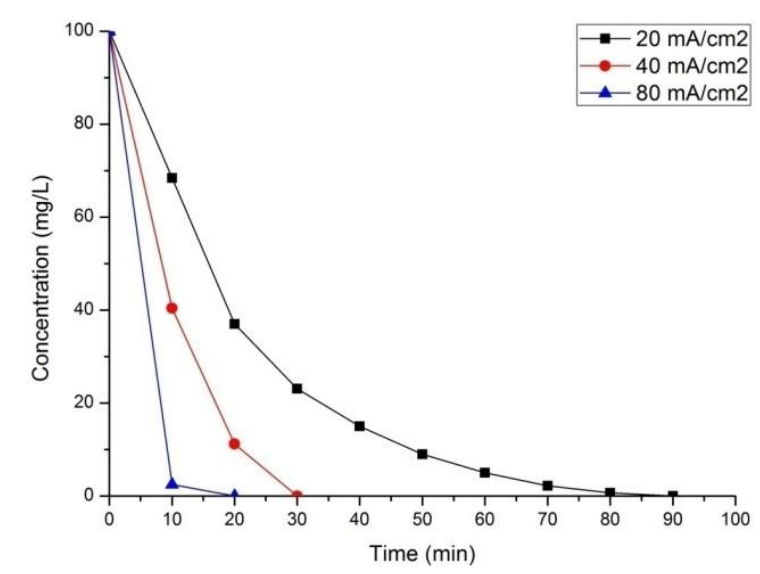

Figure 2. Residual phenol concentration versus time at various current densities

\section{Effect of temperature}

In our previous work [25] we reported complete removal of recalcitrant hydrocarbons and COD from petroleum wastewater by anodic oxidation with BDD electrodes at the elevated temperature of 60 ${ }^{0} \mathrm{C}$. Rocha et al., 2012 [26] also reported accelerated and complete anodic destruction of organics in petroleum wastewater with BDD electrodes at $60{ }^{\circ} \mathrm{C}$. In this work the anodic degradation of phenol was investigated at three different temperatures of 25,40 and $60{ }^{0} \mathrm{C}$. Figure 3 shows that the corresponding complete removal of phenol is actually accelerated as temperature rises and occurs in 90, 70 and $50 \mathrm{~min}$ of electroprocessing time. It is accepted that increased temperature favors phenol oxidation due to increased and faster indirect reaction of phenol with the electrogenerated strong oxidizing agents from the treated solution.

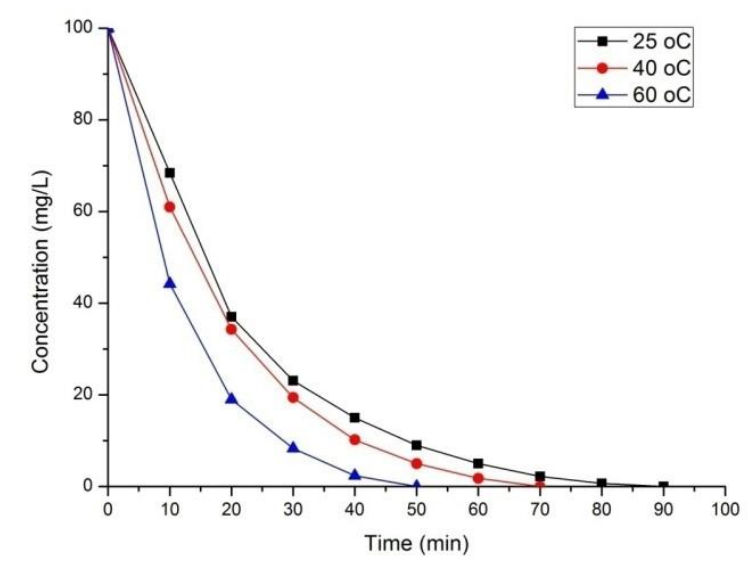

Figure 3. Residual phenol concentration versus time at various temperatures 


\section{Effect of initial phenol concentration}

To demonstrate the effect of initial phenol concentration and the time required for the quantitative COD removal, a set of experiments were conducted with three different solutions containing phenol concentrations of 100,50 and $25 \mathrm{mg} / \mathrm{L}$ with the measured COD values of 221,112 and $52 \mathrm{mg} / \mathrm{L}$ respectively. The solutions were treated at a constant current density of $20 \mathrm{~mA} / \mathrm{cm}^{2}$ and room temperature $25{ }^{0} \mathrm{C}$. Figure 4 shows the variations of the initial COD with time. The three different initial COD concentrations of 221, 112 and $52 \mathrm{mg} / \mathrm{L}$ were completely removed after 90, 50 and 30 respectively. According to Figure 4, no direct correlation exists between COD concentration and removal efficiency. Certainly, for higher COD concentrations longer time for removal is needed, but higher initial concentrations were reduced significantly in relatively less time than lower concentrations. The electrooxidation process is more effective at the beginning when the concentration is higher than at the end of the operation when the concentration is low. This can be explained by side reactions of the $\mathrm{OH}^{*}$ radicals. Due to lower concentration of phenol at the end of treatment, the highly reactive hydroxyl radicals undergo recombination of two $\mathrm{OH}^{*}$ to form $\mathrm{H}_{2} \mathrm{O}_{2}$.

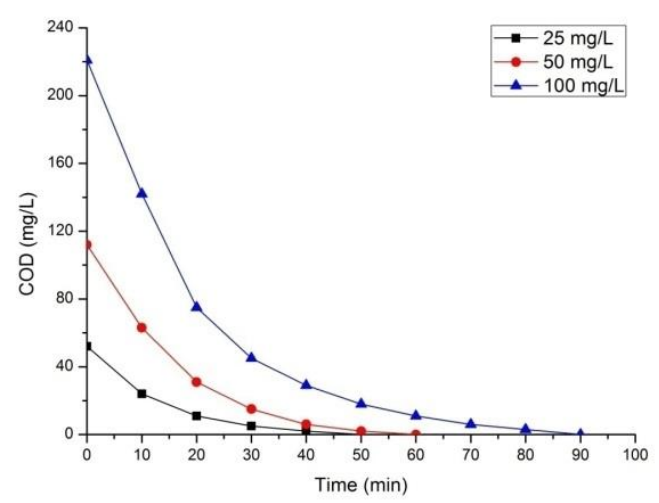

Figure 4. Residual COD versus time at various initial phenol concentrations

\section{Continuous electrooxidation process}

The continuously operated electrooxidation process is affected by the same parameters as the batch process and furthermore from wastewater flow rate, solution conductivity and residence time.

\section{Effect of flow rate}

Higher flow rates entail lower residence times. Consequently, the flow rate influences the final residual concentration and the removal percentage of phenol in the outlet stream [27]. As obtained from Figure 5, for flow rates $20-40 \mathrm{~mL} / \mathrm{min}$ the residual outlet concentration of phenol increases from 0 to $22.3 \mathrm{mg} / \mathrm{L}$, while the removal percentage drops from $>99$ to $77.6 \%$.

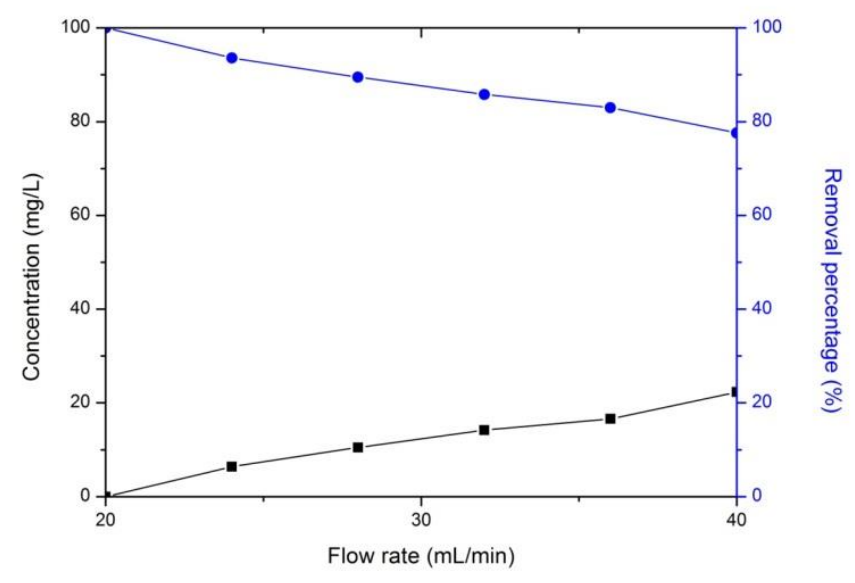

Figure 5. Phenol concentration and removal percentage in outlet stream versus flow rate 
To secure almost complete removal of phenol (>99\%) and negligible concentration in the outlet stream the current density and the applied voltage must proportionally be increased. Table 1 shows the corresponding current densities, voltages, residence times, electrical energy consumption and removal percentage of phenol for the applied flow rates $20-40 \mathrm{~mL} / \mathrm{min}$. The experiments were conducted each time by constant flow rate and proportionally constant voltage in order to keep an almost constant current density. It can be seen in Table 1, that by doubling the flow rate e.g. from 20 to $40 \mathrm{~mL} / \mathrm{min}$ also the current density must almost be doubled from 80 to $160 \mathrm{~mA} / \mathrm{cm}^{2}$ and this can occur by appropriately increasing the applied voltage and the electrical energy consumption. By increasing the current density the cell voltage and flow rate increase proportionally, while the residence time decreases. In this way, the removal percentage of phenol, expressed as COD, is hardly affected and remains high over $99 \%$ respectively in all experiments.

Table 1. Continuous electrooxidation at various flow rates and constant ratio of current density to flow rate

\begin{tabular}{cccccc}
\hline $\begin{array}{c}\text { Flow rate } \\
(\mathbf{m L} / \mathbf{m i n})\end{array}$ & $\begin{array}{c}\text { Current density } \\
\left(\mathbf{m A} / \mathbf{c m}^{\mathbf{2}}\right)\end{array}$ & $\begin{array}{c}\text { Voltage } \\
(\mathbf{V})\end{array}$ & $\begin{array}{c}\text { Residence time } \\
(\mathbf{m i n})\end{array}$ & $\begin{array}{c}\text { Energy } \\
\text { consumption } \\
\left(\mathbf{k W h} / \mathbf{m}^{\mathbf{3}}\right)\end{array}$ & $\begin{array}{c}\text { COD removal } \\
(\boldsymbol{\%})\end{array}$ \\
\hline 20 & 80 & 8.72 & 12.50 & 17.44 & $>99$ \\
24 & 96 & 9.21 & 10.41 & 18.40 & $>99$ \\
28 & 112 & 9.74 & 8.93 & 19.48 & $>99$ \\
32 & 128 & 10.26 & 7.81 & 20.51 & $>99$ \\
36 & 144 & 10.77 & 6.94 & 21.52 & $>99$ \\
40 & 160 & 11.23 & 6.25 & 22.46 & $>99$ \\
\hline
\end{tabular}

\section{Effect of conductivity}

Increased conductivity facilitates the electrochemical treatment of solutions by reducing the applied voltage and therefore the electrical energy consumption [28]. Experiments were conducted with the constant flow rate of $20 \mathrm{~mL} / \mathrm{min}$, constant current density of $80 \mathrm{~mA} / \mathrm{cm}^{2}$ and various solution conductivities 5000 to $12500 \mu \mathrm{S} / \mathrm{cm}$. Table 2 shows the corresponding variations of applied voltage and energy consumption. The removal percentage of phenol, expressed as COD, is here again hardly affected and remains constant over $99 \%$.

Table 2. Continuous electrooxidation at constant flow rate and various solution conductivities

\begin{tabular}{cccc}
\hline $\begin{array}{c}\text { Conductivity } \\
(\boldsymbol{\mu S} / \mathbf{c m})\end{array}$ & $\begin{array}{c}\text { Voltage } \\
(\mathbf{V})\end{array}$ & $\begin{array}{c}\text { Energy } \\
\text { consumption } \\
\left(\mathbf{k W h} / \mathbf{m}^{\mathbf{3}}\right)\end{array}$ & $\begin{array}{c}\text { COD removal } \\
\text { percentage } \\
(\boldsymbol{\%})\end{array}$ \\
\hline 5000 & 11.05 & 22.12 & $>99$ \\
7500 & 8.72 & 17.44 & $>99$ \\
10000 & 6.86 & 13.63 & $>99$ \\
12500 & 5.24 & 10.35 & $>99$ \\
\hline
\end{tabular}

\section{Conclusions}

Toxic and recalcitrant compounds, such as phenol can effectively be destroyed by anodic oxidation with dimensionally stable BDD electrodes. Both, batch wise and continuously operated electrooxidation processes eliminate the concentration of phenol in the treated aqueous solutions to over $99 \%$. Increased applied current density and near neutral $\mathrm{pH}$ accelerate the electrooxidation treatment and significantly reduce the electrical energy consumption. The continuous electrooxidation process can operate with various flow rates and produce phenol free outlet streams, provided that the ratio flow rate/current density is kept constant. A proportional increase of the solution conductivity brings about a significant drop in the electrical energy consumption without affecting the concentration of phenol in the outlet stream. 


\section{References}

1. SCULLY C., COLLINS G., O'FLAHERTY V., Anaerobic biological treatment of phenol at 9.5-15 ${ }^{0} \mathrm{C}$ in an expanded granular sludge bed (EGSB)-based bioreactor, Water Res. 40, 2006, 3737-3744.

12.DĄBROWSKI A., PODKOŚCIELNY P., HUBICKI Z., BARCZAK M., Adsorption of phenolic compounds by activated carbon-a critical review, Chemosphere 58, 2005, 1049-1070.

3 POPOVICI D., DUSESCU C., NEAGU M., Removal of phenol from aqueous solution on activated carbon obtained from coffee grounds, Rev. Chim. 67(4), 2016, 751-756.

4ESPLUGAS S., GIMÉNEZ J., CONTRERAS S., PASCUAL E., RODRÍGUEZ M., Comparison of different advanced oxidation processes for phenol degradation, Water Res. 36, 2002, 1034-1042.

5.GIMÉNEZ J., CURCÓ D., QUERAL M.A., Photocatalytic treatment of phenol and 2,4dichlorophenol in a solar plant in the way to scaling-up, Catalysis Today 54, 1999, 229-243.

6.MIRON A.R., CHIVU A-M., RICABI A-A.K-K., ALBU P.C., Pharmaceutical industry wastewater treatment through electrocoagulation, Rev. Chim. 65(12), 2014, 1399-1406.

7.IHOS M., IANCU V., PETRE J., Dichlofenac removal at low concentrations from wastewaters by electrochemical oxidation, Rev. Chim. 65(7), 2014, 840-843.

8.F.C. WALSH, Electrochemical technology for environmental treatment and clean energy conversion, Pure \& Appl. Chem. 73, 2001, 1819-1837.

9.DIMOGLO A., AKBULUT H.Y., CIHAN F., KARPUZCU M., Petrochemical wastewater treatment by means of clean electrochemical technologies, Clean Technol. Environ. Policy 6, 2004, 288-295.

10.PARKES J., Cleaner technologies and electrochemical reactions, J. Cleaner Prod. 2(2), 1994, 8389.

11.KHARTI I., SINGH S., GARG A., Performance of electro-Fenton process for phenol removal using iron electrode and activated carbon, J. Environ. Chem. Eng. 6(6), 2018, 7368-7376.

12.PIMENTEL M., OTURAN N., DEZOTTI M., OTURAN M.A., Phenol degradation by advanced electrochemical oxidation process electro-Fenton using a carbon felt cathode, Appl. Catalysis B: Environ. 83(1-2), 2008,140-149.

13.ALVEREZ-GALLEGOS A., PLETCHER D., The removal of phenols and related compounds from aqueous effluents, Electrochim. Acta 44, 1999, 2483-2492.

14.KRAFT A., STADELMANN M., BLASCHKE M., Anodic oxidation with doped diamond electrodes: a new advanced oxidation process, J. Hazard. Mater. B103, 2003, 247-261.

15.TROSTER I., FRYDA M., HERRMANN D., SCHAFER L., HANNI W., PERRET A., BLASCHKE M., KRAFT A., STADELMANN M., Electrochemical advanced oxidation process for water treatment using DiaChem ${ }^{\mathrm{R}}$ electrodes, Diam. Rel. Mater. 11, 2002, 640-645.

16.SUN J., LU H., LIN H., DU L., HUANG W., LI H., CUI T., Electrochemical oxidation of aqueous phenol at low temperatures using Ti/BDD electrode, Sep. Purif. Technol. 88, 2012, 116-120.

17.ALENCAR SE SOUZA R.B., RUOTOLO L.A.M., Phenol electrooxidation in different supporting electrolytes using boron-doped diamond electrodes, Int. J. Electrochem. Sci. 8, 2013, 643-657.

18.ZHAO G., SHEN S., LI M., WU M., CAO T., LI D., The mechanism and kinetics of ultrasoundenhanced electrochemical oxidation of phenol on boron-doped diamond and $\mathrm{Pt}$ electrodes, Chemosphere 73, 2008, 1407-1413.

19.SARATALE R.G., HWANG K.-J., SONG J.-Y., SARATALE G.D., KIM D.-S., Electrochemical oxidation of phenol for wastewater treatment using $\mathrm{Ti} / \mathrm{PbO}_{2}$ electrode, J. Environ. Eng. 142(2), 2016, 04015064 .

20.FERG E.E., GOUWS S. PONGOMA B., Electrochemical oxidation of phenol using a flow-through micro-porous lead dioxide/lead cell, S. Afr. J. Chem., 65(1), 2012, 165-173.

21.TASIC Z., GUPTA V.K., ANTONIJEVIC M.M., The mechanism and kinetics of degradation of phenolics in wastewaters using electrochemical oxidation, Int. J. Electrochem. Sci., 9, 2014, 34733490 .

22.WEISS J., On the stability and the reactions of the $\mathrm{H} 2 \mathrm{O}+$ ion in aqueous solution, Experientia 12, 1956, 280-281. 
23.BUXTON G.V., GREENSTOCK C.L., HELMAN W.P., Critical review of rate constants for reaction of hydrated electrons, hydrogen atoms and hydroxyl radicals $\left(\cdot \mathrm{OH}^{-} / \mathrm{O}^{-}\right)$in aqueous solution, $J$. Phys. Chem. Ref. Data, 17, 1988, 513.

24.MARTINEZ-HUITLE C.A., CHIANCA DE MOURA D., RIBEIRO DA SILVA D., Applicability of electrochemical oxidation to the treatment of petrochemical effluents, Chem. Engin. Trans., 41, $2014,373378$.

25.DERMENTZIS K., MARMANIS D., CHRISTOFORIDIS A., OUZOUNIS K., Electrochemical reclamation of wastewater resulted from petroleum tanker truck cleaning, Environ. Engin. Manage. J., 13(1), 2013, 2395-2399.

26.ROCHA J.H.B., GOMES M.M.S., FERNANDES N.S., DA SILVA D.R., MARTINEZ-HUITLE CA., Application of electrochemical oxidation as alternative treatment of produced water generated by Brazilian petrochemical industry, Fuel Process.Technol. 96, 2012, 80-87.

27.RAMALHO A.M.Z., MARTINEZ-HUITLE CA., DA SILVA D.R., Application of electrochemical technology for removing petroleum hydrocarbons from produced water using a DSA-type anode at different flow rates, Fuel 89, 2010, 531-534.

28.MARMANIS D., DERMENTZIS K., CHRISTOFORIDIS A., DIAMANTIS V., OUZOUNIS K., AGAPIOU A., STYLIANOU M., Electrochemical treatment of olive mill waste powered by photovoltaic solar energy, J. Power Technol. 98, 2018, 377-381.

$\overline{\text { Manuscript received: } 14.08 .2019}$ 